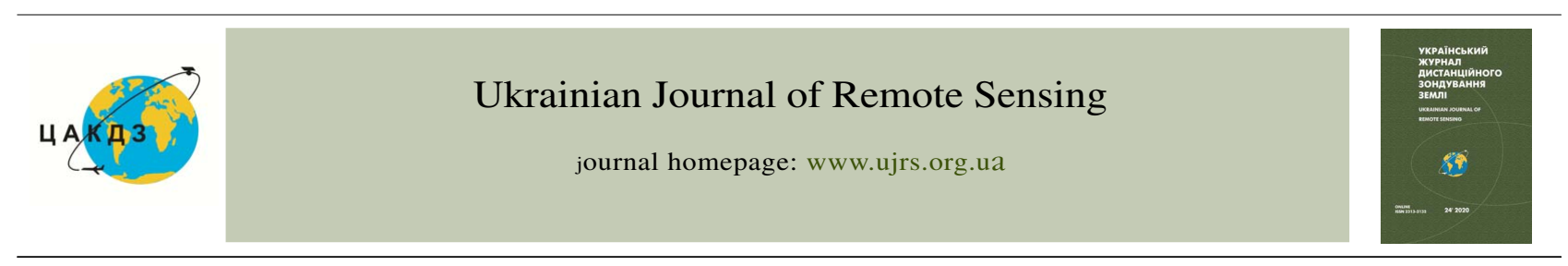

DOI: $10.36023 /$ ujrs.2020.24.162

UDC 621.396 .96

\title{
Space-borne radar observation of near-surface wind effect on anomalously highly-directional backscattering of radio waves from Aeolian processes of sand and dust transporting in desert regions
}

\author{
D. M. Bychkov, V. K. Ivanov, A. Ya. Matveyev, V. N. Tsymbal, S. Ye. Yatsevich * \\ Usikov Institute of Radio Physics and Electronics, National Academy of Sciences of Ukraine. Ak. Proskura 12, 61085, Kharkov, Ukraine
} Aeolian process of sand and dust transporting is known to form the near-ground surface structures over vast territories and fill the atmosphere up with
suspended aerosols-like dust particles which are spread then by winds over long distances. The presence of atmospheric dust in the planet's environment
is one of the factors affecting the temperature and climatic conditions of vast regions of the Earth. A number of publications (Ivanov et al., 2015;
Ivanov et al., 2016; Ivanov et al., 2016; Ivanov et al., 2018) analyze the revealed effect of anomalously highly(narrow) directed backscattering of
radio waves which manifests itself in radar remote sensing (in range of local irradiation angles $\theta \approx 31^{\circ} \div 32^{\circ}$ ) in areas covered with deep sand. At the
same time, there is no specific data available from published studies investigating the impact of the near-surface wind on anomalously highly-
directional backscattering of radio waves based on the results of radar remote sensing researches of Aeolian sand and dust transport processes in
desert regions that, in turn, could have been used later to determine the parameters of such transport process. This article presents the results of
analysis of the data obtained from long-term studies of desert regions of El-Djuf, Akshar and Trarza in Mauritania by means of space-borne SAR
Envisat-1. The purpose of the analysis was actually to identify the specifics of the effect that the near-surface wind has on the anomalously highly-
directional backscattering of radio waves which is identified by radar based researches of Aeolian processes of sand and dust transport in desert
regions, so can be used for remote determination of such transportation parameters.
Keywords: radar observation, anomalously highly-directional backscattering of radio waves, Aeolian transport of sand and dust, near-surface wind

(C) D. M. Bychkov, V. K. Ivanov, A. Ya. Matveyev, V. N. Tsymbal, S. Ye. Yatsevich. 2020

\section{Introduction}

Aeolian processes of transporting sand and dust while blown by the wind is a powerful erosive force that forms dunes, sand ripples, and fills up the atmosphere with suspended aerosols of dust particles that get spread by the winds over huge distances (Lancaster, 2009). The areas where large-scale Aeolian processes develop regularly, especially in the autumn-winter period when the wind is blowing from the northeast, are the western parts of Sahara desert (El-Djuf, Akshar and Trarza) sand dunes located in Mauritania. At many radar images of this region, an enormously intensive and highly-directional backscattering of radio waves from the sand surface was discovered which could not have been explained within the boundaries of traditional concepts of the mechanism of such scattering (Ivanov et al., 2015; Ivanov et al., 2016; Ivanov et al., 2016; Ivanov et al., 2018). In this paper we analyze the peculiarities of the effect of the near-surface wind on anomalously highly-directional backscattering of radio waves. This very notice able influence identified from radar based studies of Aeolian processes of sand and dust transport in desert regions that can be efficiently used for remote determination of the parameters of such Aeolian transport processes.

\footnotetext{
•E-mail: sey1959@gmail.com. ORCID.ORG/0000-0001-5991-8199
}

\section{Spatial variations of the near-surface wind and their effect on the anomalously highly-directional backscattering of radio waves}

Let us consider a pair of radar images of sandy ridges of the same site of the erg Amatlich beds near the village of Akzhuzht in Mauritania obtained in the high spatial resolution mode $(\sim 12 \mathrm{~m})$ by the Envisat SAR. Fig. 1 shows the SAR image of this region obtained on December 21, 2004. The direction of the near-surface wind at the time of the survey (Archive data, 2003) was heading from northeast to southwest. In the lower right corner of the image, an enlarged image of the analyzed area is shown. The three-dimensional conversion image of it is shown in Fig. 2 ( $\mathrm{X}$ and $\mathrm{Y}$ axes represent the distances along the surface, and $\mathrm{Z}$-axis - the backscattering coefficient). Similarly, Fig. 3 and 4 show SAR images of the same area of the sandy ridges of the erg Amatlich obtained on February 18, 2004 and the threedimensional representation of the SAR image of selected area respectively. The direction of the near-surface wind at the time of survey (Archive data, 2003) was heading from southwest to northeast. Fig. 5 shows the optical image of selected section of sand ridges. The figures in all the images indicate: 1 - crest of the sandy ridge, 2 - top of the large dune, 3 south-west slope of the ridge, 4 - northeast slope of the ridge. 


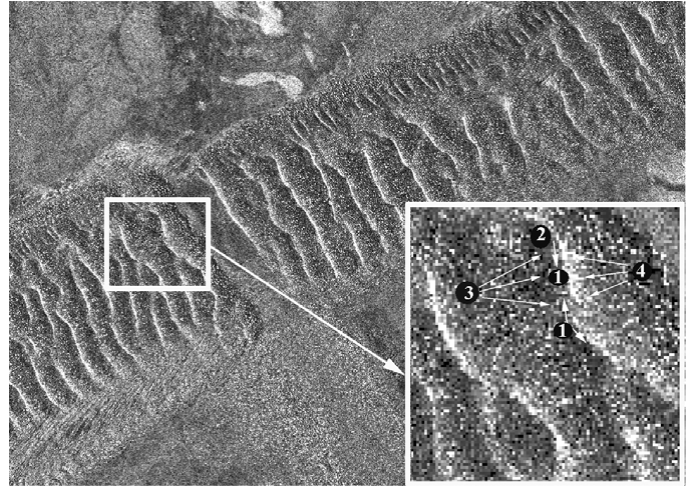

Fig. 1. SAR images of sandy ridges at the site of the erg Amatlich near the village of Akzhuzh in Mauritania obtained in high spatial resolution mode $(\sim 12 \mathrm{~m})$ by the Envisat SAR on 21.12.2004

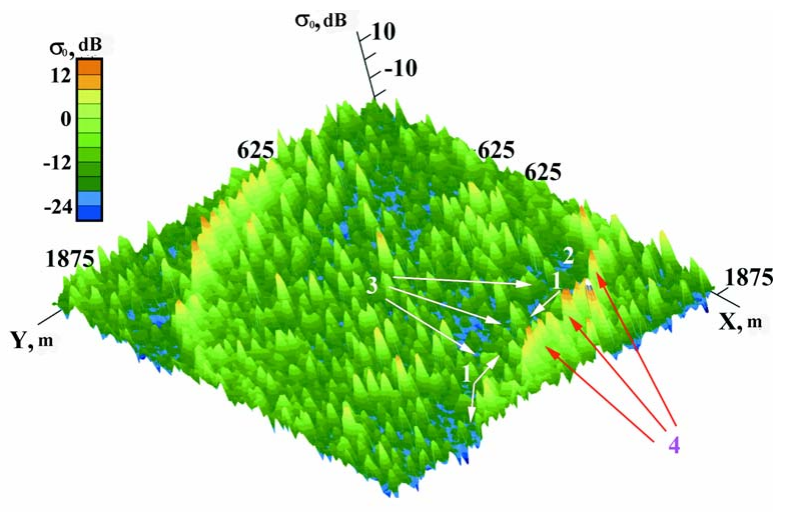

Fig. 2. Three-dimensional SAR images of the selected site 21.12.2004

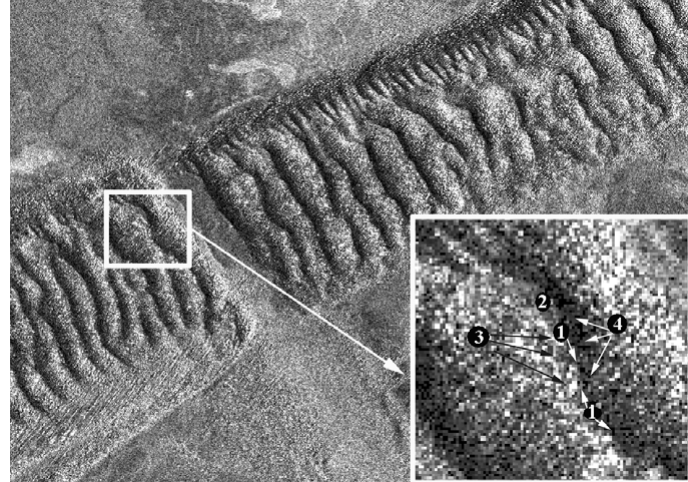

Fig. 3. SAR images of sandy ridges at the site of the erg Amatlich near the village of Akzhuzh in Mauritania obtained in high spatial resolution mode $(\sim 12 \mathrm{~m})$ by the Envisat SAR on 18.02.2004

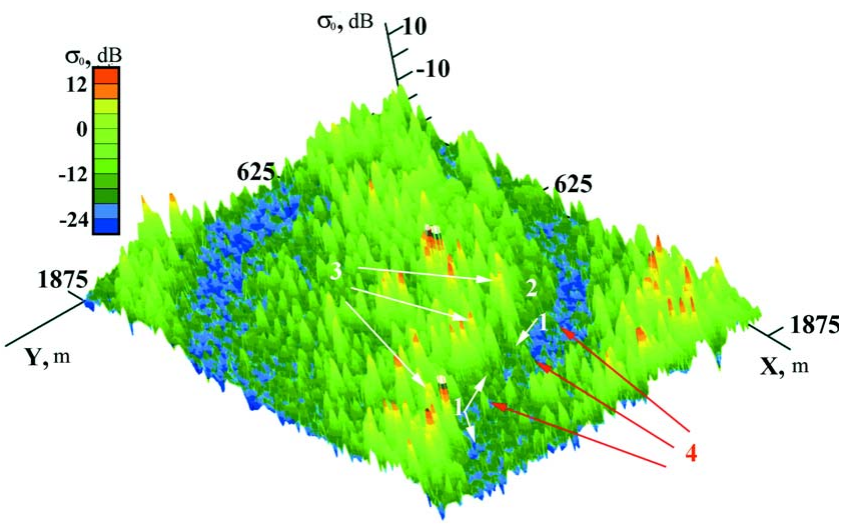

Fig. 4. Three-dimensional SAR images of the selected site 18.02.2004

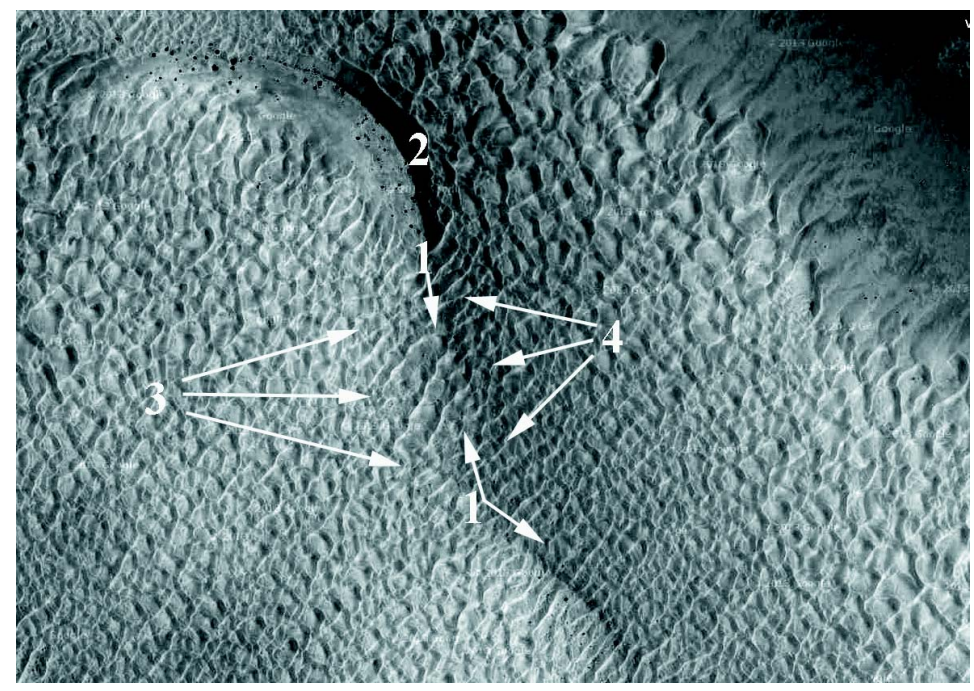

Fig. 5. Optical image (Google maps) of the selected site

The analysis of the pair of these images convincingly indicates that irrespective to the direction of the wind, the intensity of the scattering of radio waves on the leeward slope of the sandy ridge exceeds by more than $12-15 \mathrm{~dB}$ the scattering intensity from the slope located in the area of the "wind shadow". This illustrates the direct impact of the near-surface wind on the backscattering of radio waves that gets manifested in the Aeolian transport process of sand and dust in desert regions.

\section{Effect of near-surface wind on electric field near sandy surface}

Crucial impact in the ionization of the near-surface atmosphere layer of the formation of anomalously highly-directional backscattering of radio waves in the Aeolian processes of sand and dust transporting (Ivanov et al., 2015; Ivanov et al., 2016; Ivanov et al., 2016; Ivanov et al., 2018) is produced by strong 
electric fields generated as a consequence of movements and collisions of grains of sand (Kok, 2008; Stow, 1969; Namikas, 2003). In Fig. 6 (Kok, 2009), the experimental results for measuring the electric field strength at various altitudes above the surface during the Aeolian transport of sand and dust are presented. It is clearly seen that the field strength increases with decreasing the altitude very steeply, so reaching (in case of sandstorms) values of $160-250 \mathrm{kV} / \mathrm{m}$ measured at altitudes of about $1.5-2 \mathrm{~cm}$ from the surface. These strong fields ensure the fact that the bulk of the transferred sand is depressed against the

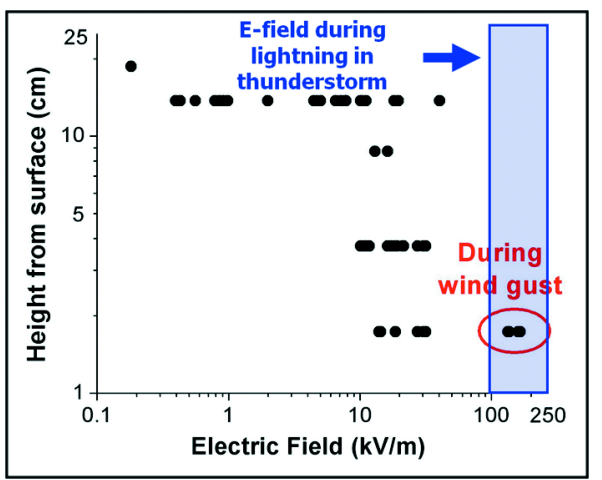

Fig. 6. Experimental results of measuring the electric field strength at various altitudes above the surface during Aeolian transport of sand and dust (Namikas, 2003)

surface. According to model (Kok, 2008; Zheng, 2013) and experimental data (Namikas, 2003, Greeley; 1996), about 50\% of the sand mass is transported in the layer $3-4 \mathrm{~cm}$ above the surface with a maximum mass flow at an altitude of about $1 \mathrm{~cm}$ above the surface.

It is also noted in (Namikas, 2003) that at field intensities of $160-250 \mathrm{kV} / \mathrm{m}$ in the transported sand and dust mass (during sand storms), the powerful lightning discharges are regularly observed. And it is emphasized that the nature of this phenomenon is not entirely understandable, since the measured field strengths do not reach the value of the breakdown voltage for clean air $(1.25 \mathrm{kV} / \mathrm{mm})$. The very air-sand-dust mixture behaves like an ionized medium - a dusty plasma. Thus, the given in (Haddad, 1983) results of an experimental study of the attenuation of microwave radiation with a frequency of $9.4 \mathrm{GHz}$ in the dust storm with a visibility of $V_{b} \approx 10 \mathrm{~m}$ and conductivity of the transferred sand of $2.634 \pm 0.734$, turned out to be $0.034 \mathrm{~dB} / \mathrm{m}$, so exceeded in more than 30 times the values pre-calculated according to the traditional radio-wave scattering theory. An analytical formula for the scattered attenuation $\mathrm{A}$ of microwave radio emission with wave number $k$ was proposed in (Zhou, 2005) under an assumption that such a strong damping is due to the influence of the inhomogeneous spatial distribution of the electric charge with the surface density $\sigma_{q}$ over the sand grains surface relative to the observation angle $\theta \sigma_{0}$ :

$$
\begin{gathered}
A=\frac{20}{V_{b}} k^{4} D_{s}^{4}\left[\frac{\varepsilon_{s}-\varepsilon_{0}}{\varepsilon_{s}+2 \varepsilon_{0}}\right]^{2}+\frac{90}{v_{b}} D_{s} k \varepsilon^{\prime \prime}{ }_{y}\left[\frac{\varepsilon_{s}-\varepsilon_{0}}{\varepsilon_{s}+2 \varepsilon_{0}}\right]^{2}+ \\
+\frac{7.5}{9} k^{4} D_{s s}^{6} C_{\vartheta} \frac{\rho_{s}^{2}\left(\varepsilon_{s}-\varepsilon_{0}\right)^{2} \sin \theta_{\sigma 0}^{2}}{\varepsilon_{0}^{2} E_{i}\left(1-\cos \theta_{0}\right)^{2} v_{b}}
\end{gathered}
$$

where -is the diameter of the grains of sand, -is the conductivity of air, -is the surface conductivity of grains of sand, -is the conductivity of grains of sand relative to air, -is the total electric charge of the grains of sand, -is the density of grains of sand, $\mathrm{Ei}$ - is the radiation field strength.

At the same time, the experimental results (Mohd Taufik, 2014) convincingly show that, when irradiating the plasma formations with radio emission at a frequency equal to or exceeding the natural plasma frequency, it behaves as a partially scattering dielectric medium with losses (Fig. 7). The sand-dust mixture

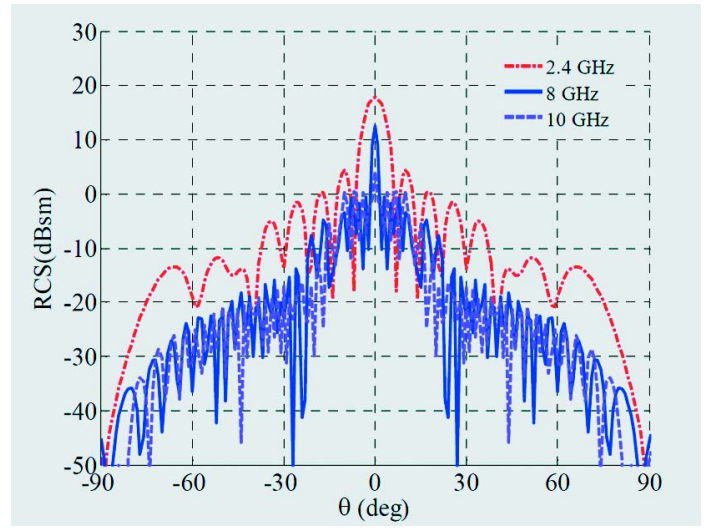

Fig. 7. Experimental dependences (Mohd Taufik, 2014) of the backscattering coefficient of a planar rectangular plasma formation upon irradiation of radio emission: 1) $2.4 \mathrm{GHz}$ - with a frequency much lower than the natural plasma frequency, 2) $8 \mathrm{GHz}$ - with a frequency that coincides with the plasma natural frequency and 3) $10 \mathrm{GHz}$ - with a frequency exceeding the natural frequency of the plasma

exposed to microwave irradiation behaves in the similar way while being under the influence of a strong electric field.

\section{Effect of the near-surface wind velocity on the intensity of anomalously highly-directional backscattering of radio waves during the Aeolian transport of sand and dust}

Determination of intensity dependency of the anomalously highly-directional backscattering of radio waves during the Aeolian process of sand and dust mixture transporting was carried out based on the archived radar images obtained by the Envisat1 satellite. The images were provided by ESA within the project ID: C1F.30193. Selection of the images was held with the help of EOLI-SA online catalog while taking into account meteorological data on the direction and velocity of near-surface wind (Taufic). The images were also calibrated by ESS (effective scattering surface), tied to the map, and thematically processed by the normally applied software freely distributed by ESA for image processing purposes: NEST 4B-1.0 and NEST 5.1.

In order to determine the maximum values of the scattering intensity, the graphs were plotted in the way similar to (Ivanov et al., 2015; Ivanov et al., 2016; Ivanov et al., 2016; Ivanov et al., 2018) for dependencies of the backscattering coefficient $\sigma_{0}$ on the angle of local irradiation $\theta$ along the sections of the fragments of the most homogeneous parts of the radar images of the surface on which the effects of anomalously highly directed backscattering of radio waves are observed. The maximum values of $\sigma$ were chosen in the range of incidence angles of radio waves: $\theta=31^{\circ}-32^{\circ}$.

Fig. 8a shows the fragment of SAR image of Trarza desert area (Envisat-1 ASA_GM1_1P, 2012-01-12), and Fig. 8b shows 


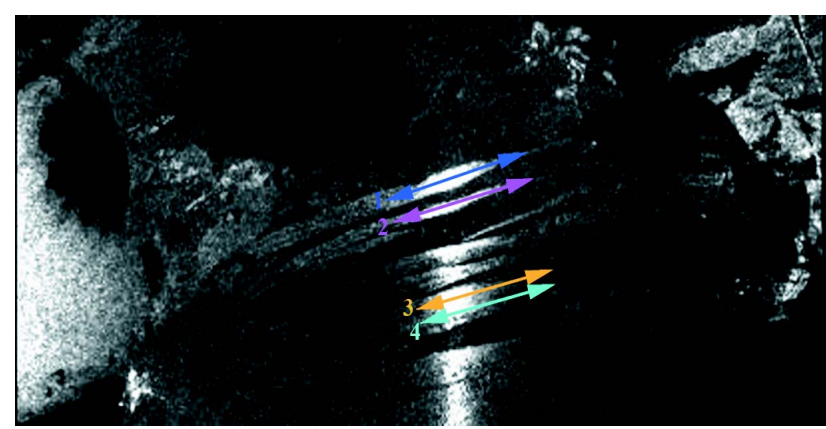

a

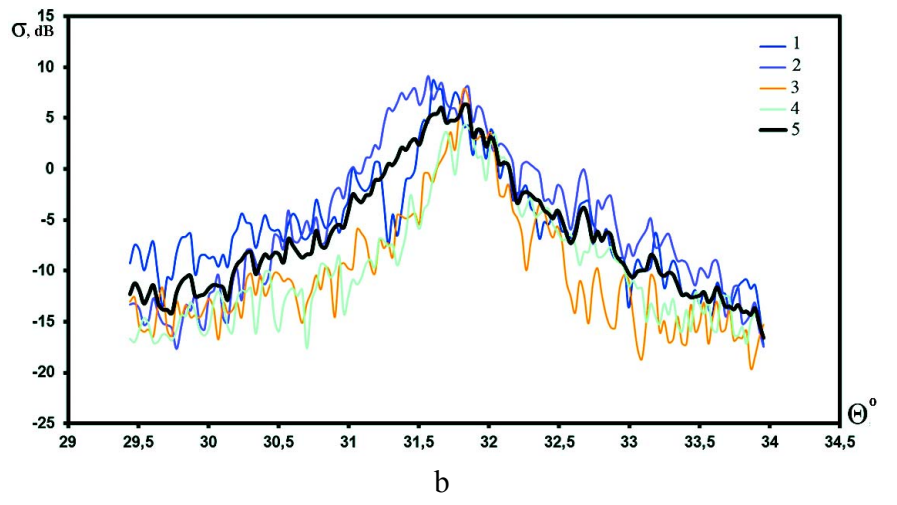

Fig. 8. $a$ - fragment of SAR image of Trarza desert area (Envisat-1 ASA_GM1_1P, 2012-01-02), b — respective graphs of dependencies of $\sigma$ from local irradiation angle $\theta$ along the fragments sections. The cross-sections are made along the most uniform regions of the surface reflected at the image where the effects of anomalously highly-directional backscattering of radio waves are visible. The more dense black color refers to the average of the dependences of $\sigma(\theta)$

the corresponding graphs of dependencies of the backscattering coefficient $\sigma$ from the local irradiation angle $\theta$ along the sections of the fragments. The cross-sections are made along the most uniform regions of the surface reflected on the image where the effects of anomalously highly directed backscattering of radio waves are observed. The more dense black color refers to the average of the dependences of $\sigma(\theta)$.

Fig. 9 depicts the dependency of maximum values of ESS coefficients $\left(\sigma_{0}\right)$ from the averaged (within $\pm 1 \mathrm{~m} / \mathrm{s}$ ) near-surface wind speed values given to the height of $1 \mathrm{~m}$ above the surface at the radar images of desert area surface in Western Sahara Desert (ElDjouf, Akshar and Trarza) located in Mauritania. The graphs are extracted for the image regions that exhibited effects of anomalously highly-directional backscattering of radio waves (irradiated in the direction opposite to the blowing direction of the near-surface wind).

It is clearly seen that the intensity of backscattering increases steeply at speeds of near-surface wind of $2 \mathrm{~m} / \mathrm{s}$ and higher. At the high wind speeds, the strong dependency of the scattering

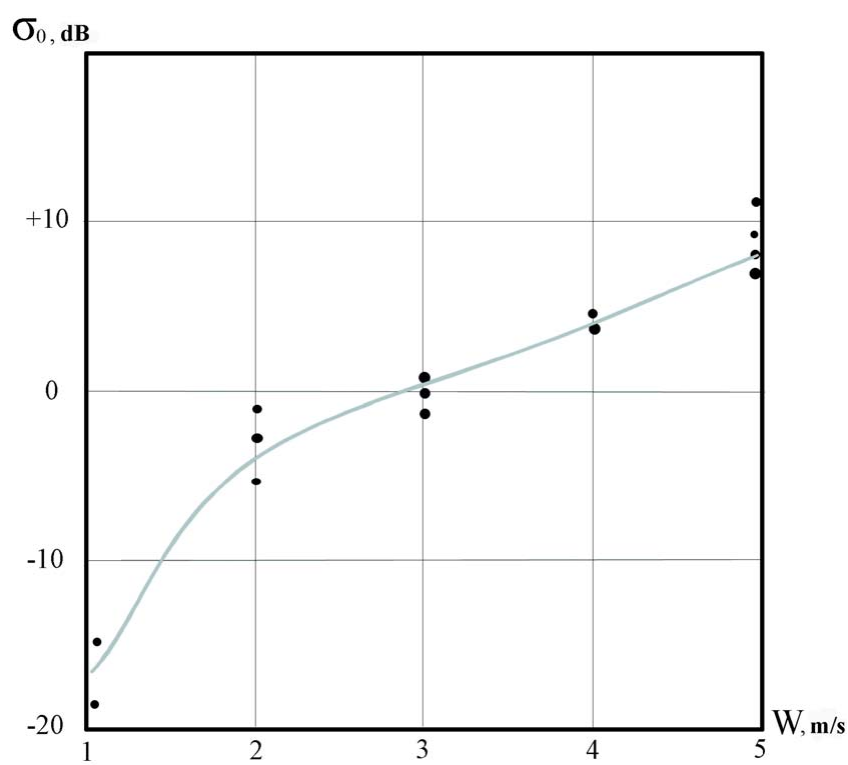

Fig. 9. Dependency of the maximum of backscattering values $\sigma_{0}$ on the radar images of desert surface areas in Western Sahara Desert (El-Djouf, Akshar and Trarza) located in Mauritania, that exhibited the effects of anomalously highly-directional backscattering of radio waves (irradiated in the direction opposite to the blowing direction of the near-surface wind), from the averaged (within $\pm 1 \mathrm{~m} / \mathrm{s}$ ) near-surface wind speed normalized to the altitude of $1 \mathrm{~m}$ above the surface towards the sandy surface in the direction coinciding (in horizontal plane) with the wind blowing direction, the manifestations of anomalously highly-directional backscattering of radio waves were not observed. The value of $\sigma_{0}$ did not exceed $-23 \mathrm{~dB}$.

\section{Conclusions}

The article studies the experimental results of persistent multiyear (2004-2012) observations of desert regions of El-Djouf, Akshar and Trarza in Mauritania by the means of space-borne SAR Envisat-1.The research is aimed at identifying the specifics of the near-surface wind impact at anomalously highly-directional backscattering of radio waves in radar based registration of Aeolian processes of transporting sand and dust in desert areas. The observational data with high spatial resolution gives strong evidences that the spatial distribution of the maximum values of intensities of the backscattered radio waves directly correlates with the spatial distribution of the near-surface winds. The intensity of the backscattered radio waves (when irradiated along the direction of near-surface wind blowing) steeply increases with the near-surface wind speed starting from the speeds of $2 \mathrm{~m} / \mathrm{s}$ (normalized to height of $1 \mathrm{~m}$ above the surface). At high wind speeds, the stable dependency of the backscattered intensity from the wind speed is confirmed. This, in turn, opens the way for development of techniques for remote parameters estimation of Aeolian processes of transporting sand and dust based on spaceborne radar imaging. When in radar remote sensing, a sandy surface gets illuminated in direction coinciding with the wind blowing direction, no anomalously highly-directional backscattering of radio waves could have been observed.

The work was carried out within the framework of the project with ESA ID: C1F30193.

\section{References}

Archive data of the meteorological website. (2003). Retrieved from http:/ /www.wetter3.de/ Archiv/index.html.

Greeley, R., Blumberg, D. G., Williams, S. H. (1996) Field measurements of the flux and speed of wind-blown sand. Sedimentology, 43(1), 41-52.

Haddad, S., Salman, M. J. H., Jha, R. K. (1983). Effects of Dust Sandstorms on Some Aspects of Microwave Propagation. Proc. URSI Commission F Symposium, Louvain-la-Neuve: ESA publication. 194, 153-161.

Ivanov, V. K., Matveyev, A. Ya., Tsymbal, V. N., Yatsevich, S. Ye. and Bychkov, D. M. (2015). Radar investigations of the aeolian sand 
and dust transporting manifestations in desert areas. Telecommunications and RadioEngineering. 74 (14), 1269-1283.

Ivanov, V. K., Matveyev, A. Ya., Tsymbal, V. N., Yatsevich, S. Ye. and Bychkov, D. M. (2016). Radar identification of desert regions as suppliers of dust in the atmosphere. Telecommunications and RadioEngineering. 75 (10), 937-948.

Ivanov, V. K., Matveyev, A. Ya., Tsymbal, V. N., Yatsevich, S. Ye. and Bychkov, D. M. (2016). Spaceborne radar identification of desert regions as suppliers of dust into the atmosphere. Ukrajinsjkyj zhurnal dystancijnogho zonduvannja Zemli. 11, 39-47. Retrieved from https:/ /ujrs.org.ua/ujrs/article/view/87/pdf.

Ivanov, V. K. (Eds.) (2018). Radar monitoring of natural and anthropogenic hazardous phenomena. (Part 2). Lambert Academic Publishing, Germany. Retrieved from https: // www.lappublishing.com.

Kok, J. F., Renno, N. O. (2008). Electrostatics in Wind-Blown Sand. Physical Review Letters, 100, 014501.

Kok, J. F. (2009). Understanding wind-blown sand and the electrification of granular systems by Jasper F. (2009). A dissertation submitted in partial fulfillment of the requirements for the degree of Doctor of
Philosophy (Appl. Physics) in The University of Michigan. Retrieved from https://deepblue.lib.umich.edu/bitstream/handle/2027.42/ 63669/jfkok_1.pdf?sequence $=1$ \&isallowed $=\mathrm{y}$

Lancaster, N. (2009) Aeolian features and processes. The Geological Society of America, 1-25. Retrieved from https:// www.nature.nps.gov/geology/monitoring/files/geomon-01.pdf.

Mohd Taufik Jusoh Tajudin. (2014). Study and design of reconfigurable antennas using plasma medium. Universite Rennes 1, access mode: https://tel.archives-ouvertes.fr/tel-01060295.

Namikas, S. L. (2003). Field measurement and numerical modeling of Aeolian mass flux distributions on a sandy beach. Sedimentology. 50, 303-326.

Stow, C. D. (1969). Dust and sand storm electrification. Weather. 24(4), $134-137$.

Zheng, X. J. (2013). Electrification of wind-blown sand: Recent advances and key issues. The European physical journal E. 36, 138

Zhou, Y.H. Shu, Qin He, Jing, Xiao (2005). Zheng Attenuation of electromagnetic wave propagation in sandstorms incorporating charged sand particles. The European Physical Journal E. 17(2), $181-187$.

КОСМІЧНЕ РАДІОЛОКАЦЙНЕ СПОСТЕРЕЖЕННЯ ВПЛИВУ ПРИПОВЕРХНЕВОГО ВІТРУ НА АНОМАЛЬНО ВУЗЬКОСПРЯМОВАНЕ РОЗСІЮВАННЯ РАДІОХВИЛЬ ПРИ ЕОЛОВОМУ ТРАНСПОРТУВАННІ ПІСКУ ТА ПИЛУ У ПУСТЕЛЬНИХ ОБЛАСТЯХ

Д. М. Бичков, В. К. Іванов, О. Я. Матвєєв, В. М. Цимбал, С. Є. Яцевич. Інститут радіофізики та електроніки ім. А Я. Усикова НАН України. Ак. Проскури 12, 61085, Харків, Україна

Еолові процеси транспортування піску та пилу формують поверхні великих територій та завантажують атмосферу суспензійованими аерозолями пилу, що розповсюджуються вітрами на великі відстані. Присутність атмосферного пилу в навколишньому середовищі планети являється одним із факторів, що впливають на температуру та кліматичні умови просторих регіоні Землі. В ряді праць аналізується виявлений ефект аномально вузькоспрямованого зворотного розсіювання радіохвиль при радіолокаційному дистанційному зондуванні (в діапазоні локальних кутів опромінення поверхні $\theta \approx 31^{\circ} \div 32^{\circ}$ ). В той же час в літературі відсутні дані стосовно особливостей впливу при поверхневого вітру на ефекти розсіювання, які можуть бути використані для визначення параметрів еолового транспортування піску та пилу. В статті наведено результати аналізу даних багаторічного дослідження пустельних районів Ель-Джуф, Акшар і Трарза в Мавританії космічним РСА Envisat-1. Ціллю аналізу було виявлення особливостей впливу приповерхневого вітру на аномально вузькоспрямоване зворотне розсіювання радіохвиль при радіолокаційному дистанційному зондуванні процесів еолового транспортування піску та пилу в пустельних районах, що можуть бути використані для дистанційного визначення параметрів цих процесів.

Дані спостережень з високим просторовим розрізненням переконливо свідчать, що просторове розповсюдження максимальних значень інтенсивності зворотного розсіювання радіохвиль відповідає просторовому розповсюдженню приповерхневого вітру. Інтенсивність зворотного розсіювання (при радіолокаційному опроміненні назустріч приповерхневому вітру) стрімко зростає при швидкостях приповерхневого вітру починаючи з 2 м/ $c$ (приведених до висоти у 1 м над поверхнею). При більших швидкостях вітру спостерігається стійка залежність інтенсивності розсіювання від швидкості вітру, що дозволяє відпрацьовувати методики визначення параметрів еолового транспортування ріску та пилу за допомогою космічної радіолокаційної інформації.

Ключові слова:радіолокаційне спостереження, аномально вузькоспрямованне розсіювання радіохвиль, еолове транспортування піску та пилу, приземний вітер

КОСМИЧЕСКОЕ РАДИОЛОКАЦИОННОЕ НАБЛЮДЕНИЕ ВОЗДЕЙСТВИЯ ПРИПОВЕРХНОСТНОГО ВЕТРА НА АНОМАЛЬНО УЗКОНАПРАВЛЕННОЕ РАССЕЯНИЕ РАДИОВОЛН ПРИ ЭОЛОВОЙ ТРАНСПОРТИРОВКЕ ПЕСКА И ПЫЛИ В ПУСТЫННЫХ ОБЛАСТЯХ Д. М. Бычков, В. К. Иванов, А. Я. Матвеев, В. Н. Цымбал, С. Е. Яцевич. Институт радиофизики и электроники им. А. Я. Усикова НАН Украины. Ак. Проскуры 12,61085, Харьков, Украина

Эоловые процессы транспортировки песка и пыли формируют структуру поверхности огромных территорий и загружают атмосферу взвешенными аэрозолями пыли, распространяющимися ветрами на огромные расстояния. Присутствие атмосферной пыли в окружающей среде планеты является одним из факторов, влияющих на температуру и климатические условия обширных регионов Земли. В ряде работ анализируется выявленный эффект аномально узконаправленного обратного рассеяния радиоволн, проявляющийся при радиолокационном дистанционном зондировании (в диапазоне локальных углов облучения поверхности $\theta \approx 31^{\circ} \div 32^{\circ}$ ) на участках, покрытых глубоким песком. В то же время в литературе отсутствуют данные об особенностях воздействия приповерхностного ветра на эффекты рассеяния радиоволн, проявляющиеся при радиолокационных исследованиях эоловых процессов транспортировки песка и пыли в пустынных районах, которые могут быть использованы для определения параметров такой транспортировки. В статье анализируются экспериментальные результаты многолетних (2004-2012 гг.) исследований пустынных районов Эль-Джуф, Акшар и Трарза в Мавритании космическим PCA Envisat-1, направленных на выявление особенностей воздействия приповерхностного ветра на аномально узконаправленное обратное рассеяние радиоволн, проявляющееся при радиолокационных исследованиях эоловых процессов транспортировки песка и пыли в пустынных районах. Данные наблюдений с высоким пространственным разрешением убедительно свидетельствуют, что пространственное распределение максимальных значений интенсивности обратного рассеяния радиоволн соответствует пространственному распределению приповерхностного ветра. Интенсивность обратного рассеяния радиоволн (при радиолокационном облучении навстречу приповерхностному ветру) резко возрастает при скоростях приповерхностного ветра начиная со значений в 2 м/c (приведенных к высоте 1 м над поверхностью). При больших скоростях ветра наблюдается устойчивая зависимость интенсивности рассеяния от скорости ветра, что позволяет отрабатывать методики оценки параметров эоловой транспортировки песка и пыли по космической радиолокационной информации. При облучении песчаной поверхности вслед ветру проявлений аномально узконаправленного обратного рассеяния радиоволн не наблюдалось.

Ключевые слова: радиолокационное наблюдение, аномально узконаправленное обратное рассеяние радиоволн, эоловый перенос песка и пыли, приземный ветер 